\title{
The Climate Debate Held Hostage by the G2
}

Jean-Paul Maréchal

Translator. N. Jayaram

\section{OpenEdition}

\section{Journals}

Electronic version

URL: http://journals.openedition.org/chinaperspectives/5383

DOI: 10.4000/chinaperspectives.5383

ISSN: 1996-4617

\section{Publisher}

Centre d'étude français sur la Chine contemporaine

\section{Printed version}

Date of publication: 1 January 2011

Number of pages: $56-62$

ISSN: 2070-3449

\section{Electronic reference}

Jean-Paul Maréchal, «The Climate Debate Held Hostage by the G2 », China Perspectives [Online],

2011/1 | 2011, Online since 30 March 2014, connection on 28 October 2019. URL : http://

journals.openedition.org/chinaperspectives/5383; DOI : 10.4000/chinaperspectives.5383

(c) All rights reserved 


\section{The Climate Debate Held Hostage}

by the $\mathrm{G} 2$

IEAN-PAUL MARÉCHAL*

Real optimism lies in saying that the next 25,000 years will be very difficult. - Romain Gary

A year after the Copenhagen Summit, the Cancun Conference (29 November-11 December 2010) showed that, despite some progress, nothing decisive will happen in facing up to climate change without the engagement of the United States as well as the People's Republic of China. In the climate arena, as in so many others, the G2 has in fact emerged as a global axis, and countless difficulties that punctuated attempts to draw up an indispensable "post-Kyoto" regime from Bali (December 2007) to Tianjin (October 2010) can be seen as so many signs of the general reconfiguration of the post-Cold War international system - a reconfiguration taking neither the form of unipolarity centred on American hyperpower (dreaded by some) nor of multipolarity (hoped for by others), but rather of Washington-Beijing bipolarity. Of course, the European Union (27-strong) accounts for a quarter of the world's GDP and must play a major role in drawing up a more equitable international order. Unfortunately, divergences among its members on climate, currency, defence, and the trans-Atlantic link, among others, keep it from converting its unique institutional structure into political will. As Chris Patten wrote in 2010, "Europe is not and will not become a superpower or superstate. Unlike the US we do not matter everywhere." (1)

China, on the other hand, has been making its voice heard and extending its influence widely on the international scene. The Middle Kingdom is now an indispensable supplier of funds to the United States and to many Third World countries, as well as to Greece and even Portugal. It is no longer the workshop of the world, as it had been dubbed only recently. It has emerged as a development model admired by many governments in the global south. This ascent is illustrated by the fact that some people are now talking about an emerging "Beijing Consensus" to supplant the now defunct "Washington Consensus."

This rearrangement of the global chessboard is not without implications for the "climate question," which is becoming more serious even as its resolution is getting complicated. This double effect appears clearly as much in the analysis of historic and prospective links between the economic evolution of the $\mathrm{G} 2$ members and their greenhouse gas emissions as in the examination of possible solutions leading to a new climate regime.

\section{$\mathrm{G} 2$ and $\mathrm{CO}_{2}$}

In July 2009, during the first US-China Strategic and Economic Dialogue in Washington, President Barack Obama declared, "The relationship between the United States and China will shape the twenty-first century." Of course, all political talk has a performative focus. All the same, the least that can be said about this quote is that it is confirmed by all available indicators, be they measures of economic might or (present and future) responsibility for climate change.

\section{The world's top two economies (in PPP terms)}

Calculated in "purchasing power parities" (PPP) terms, (2) the US and Chinese gross domestic products are the world's two highest. Measured against current exchange rates, China inevitably recedes to third place behind Japan, but it is nevertheless ahead of Germany, France, and Britain. (3) This position caps three decades of sustained, exceptional economic growth following the Deng Xiaoping-initiated shift towards capitalism in 1978, further consolidated through stepped-up liberalisation (and opening) of the economy after the 1989 Tiananmen massacre ${ }^{(4)}$ (symbolised by Deng's "southern tour" of 1992). Thus, between 1980 and 2008, that is, in a little over a quarter of a century, the Chinese GDP (PRC and Hong Kong in current exchange rates) leapt from $\$ 243.1$ billion (2000) to $\$ 2,843.9$ billion, a nearly 12 -fold rise, or a 9.2 percent growth rate. Meanwhile (using the same calculations), the GDP of the United States rose from $\$ 5,142.1$ billion to $\$ 11,742.3$ billion, that is 2.3 times, with a growth rate just under 3 percent (Table 1). In purchasing power parity terms, China's "recovery" is even more impressive (Table 2). Thus, by any calculation, the G2 today represents more than a third of global GDP.

An essential fact that is part of these changes: the US and Chinese economies have developed a veritable symbiosis, an amazing phenomenon given that their political systems are profoundly at loggerheads in terms of basic values: one a liberal democracy, the other a dictatorship (officially) professing communism. But unlike US-Soviet relations, which pitted two systems with all-round divergences on both the political and economic planes, Sino-US ties interweave rivalry (ideological, strategic...) with interdependence (economic). During the Cold War, issues such as the undervaluing of the rouble against the dollar or sovereign US debt held by the Soviets or even the volume of US imports from the Soviet Union were simply never raised.

Jean-Paul Maréchal is Associate Professor of economics at Université Rennes 2. He is a researcher at Cress-Lessor (Centre régional de recherches en sciences sociales - Laboratoire d'économie et de sciences sociales de Rennes). His last book: Humaniser l'économie (Desclée de Brouwer, 2008), was awarded the prize of the French Academy of Moral and Political Sciences.

1. Chris Patten, "What Is Europe to Do?," The New York Review of Books, vol. 57, no. 4, 11 March 2010, pp. 11-12.

2. PPP statistics replace normal exchange rates with rates designed to equalise the prices of a standard basket of goods and services.

3. It may be recalled that China was in fourth place in 2007 and overtook Germany in 2008. (See The Economist, Pocket World in Figures. 2010 Edition, London, Profile Books, 2009, p. 26, and The Economist, Pocket World in Figures. 2011 Edition, London, Profile Books, 2009, p. 24.)

4. See Barry Naughton, "The Impact of the Tiananmen Crisis on China's Economic Transition," China Perspectives, no. 2, 2009, pp. 63-79. 
Table 1 - G2 GDP (Using current exchange rates - billion 2000 US dollars)

\begin{tabular}{l|c|c|c|c}
\hline Country & 1980 & $\mathbf{2 0 0 8}$ & $\mathbf{2 0 0 8 / 1 9 8 0}(\%)$ & Annual growth rate (\%) \\
\hline United States & $5,142.1$ & $11,742.3$ & 2.3 & 2.9 \\
\hline China (including Hong Kong) & 243.1 & $2,843.9$ & 11.7 & 9.2 \\
\hline G2 & $5,385.2$ & $14,586.2$ & 2.7 & \\
\hline World & $18,137.9$ & $40,481.5$ & 2.2 & 2.9 \\
\hline G2/world (\%) & 29.7 & 36.0 & & \\
\hline
\end{tabular}

Source: Based on International Energy Agency data. $\mathrm{CO}_{2}$ Emissions from Fuel Combustion, Highlights. 2010 Edition. (Text available on the Internet).

Table 2 - G2 GDP (Using purchasing power parities - billion 2000 US dollars)

\begin{tabular}{l|c|c|c|c}
\hline Country & 1980 & 2008 & $2008 / 1980(\%)$ & Annual growth rate (\%) \\
\hline United States & $5,142,1$ & $11,742.3$ & 2.3 & 2.9 \\
\hline China (including Hong Kong) & 821.7 & $11,053.7$ & 13.5 & 9.7 \\
\hline G2 & $5,963.8$ & $22,796.0$ & 3.8 & \\
\hline World & $25,098.3$ & $63,865.8$ & 2.54 & 3.4 \\
\hline G2/world (\%) & 23.7 & 35.7 & & \\
\hline
\end{tabular}

Source: Based on International Energy Agency data, $\mathrm{CO}_{2}$ Emissions from Fuel Combustion, Highlights. 2010 Edition. (Text available on the Internet)

Who would say the same about the Chinese economy now? (5) Many experts say the yuan is undervalued by 20 percent to 40 percent against the dollar, resulting in US importing four times more to China than it exports. At the same time, China has been making bulk purchases of US treasury bonds, thus financing the American debt and deficit. The US treasury is replenished up to a billion dollars a day, with China having accumulated about $\$ 800$ billion in American bonds. Beijing and Tokyo have thus become Washington's top creditors, and China the state with the least interest in seeing the dollar collapse. Actually, China's foreign exchange reserves amount to \$2,500 billion, about two-thirds of it (still) in US dollars. The Soviet Union's bankruptcy, wished (and accelerated, even provoked?) (6) by the United States, did not have the slightest repercussion on the latter, which by the 1990s had become a hyperpower. But the collapse of either of the two economies - Chinese or US - will have incalculable consequences for the other. The term "Chimerica," (7) coined in 2007, seeks to capture this enmeshing - or fusion, as some would have it ${ }^{(8)}$ - of the world's top two economies.

In a sign of how times have changed, the US President preferred to attend the ASEAN Summit in November 2009 rather than to visit Germany for the twentieth anniversary of the fall of the Berlin Wall. In January 2009, Zbigniew Brzezinski, who was an adviser to Barack Obama before the 2008 presidential campaign, wrote an article in the Financial Times entitled "The Group of Two that Could Change the World." "(9) He noted that Sino-US ties must be a comprehensive partnership, an "informal G2." He also noted that China was a "revisionist power" seeking to tilt the balance of forces in its favour, and that consequently, cooperation between the two giants won't be without rivalries. A few weeks later, on 6 March 2009, Robert Zoellick and Justin Yifu Lin - president and chief economist, respectively, of the World Bank - wrote in the Washington Post that a solution to the crisis required cooperation between China and the United States and that the two had to become "the engine for the Group of 20." (10)

To consider just one economic domain, Beijing in 2005 declared it wanted to quadruple its GDP by 2020. Although the crisis that erupted in 2008 led to worries, given that Chinese exports were badly hurt by the slow-down in Western economies, the two-year recovery plan the government announced in November 2008 seems to have borne fruit: 9.1 percent growth in 2009, as much as 10.5 percent in 2010, and 9.6 percent projected for 2011. And these figures for the Middle Kingdom's growth perspectives will not, of course, disprove Brzezinski. Despite the inherent weakness of any long-term forecast, a number of broad-brush features are discernible. Claude Meyer has said, for example, that "barring major political or social crisis, China could become the world's top economy by 2030." (11)

A distinct feature of the current situation, and of the foreseeable future, is that the world economy will be dominated in the decades to come by two countries with different stages of development. Despite its spectacular rise, China remains an emerging economy, as seen from the comparison of the US and Chinese GDPs. This gap is undeniable. Even if calculated in PPP (Table 3), which tends to reflect real differences in standards of living better than calculations based on current exchange rates, an American would still be eight times richer than a Chinese resident. Such disparity, as it will be seen, compounds the difficulty of resolving the climate problem.

The $\mathrm{G} 2$ is not only the club of the two global economic leaders; it is also one of the planet's two top emitters of greenhouse gases.

\section{The world's two biggest polluters}

These figures are also undeniable. In 2008, the United States released into the atmosphere 5.6 billion tonnes (gigatonnes or $\mathrm{Ct}$ ) of $\mathrm{CO}_{2}$ and $\mathrm{China}$

5. Unless otherwise stated, figures in this paragraph are taken from the figures cited by Bernard Poulet in "Chine maitre du monde" (China, world leader), L'Expansion, no. 747, December 2009.

6. At least the Soviets didn't get there by themselves. On this, an interesting account is by Gerald K. Haines and Robert E. Leggett, Watching the Bear: Essays on CIA's Analysis of the Soviet Union. (Available on the CIA website.)

7. Niall Ferguson and Moritz Schularick coined it. See Niall Ferguson and Moritz Schularick, '"Chimerica' and the Global Asset Market Boom," International Finance, 10:3, 2007, pp. 215-239.

8. Zachary Karabell, Superfusion: How China and America Became one Economy and Why the World's Prosperity depends on It, New York, Simon \& Schuster, 2009, 340 pp.

9. Z Zbigniew Brzezinski, "The Group of Two that Could Change the World," Financial Times, London, 13 January 2009.

10. Robert B. Zoellick and Justin Yifu Lin, "Recovery Rides on the 'G2'," Washington Post, 6 March 2009.

11. Claude Meyer, Chine ou Japon. Quel leader pour l'Asie? (China or Japan: Which leader for Asia?), Paris, Les Presses de Sciences Po, 2010, p. 170 
Table 3 - 2008 GDP per capita for the G2

\begin{tabular}{l|c|c}
\hline Country & Actual exchange rates (US\$) & In purchasing power parity \\
\hline United States & 46,350 & 100 \\
\hline China & 3,270 & 12.9 \\
\hline US/China & 14.17 & 7.7
\end{tabular}

Source: The Economist, Pocket World in Figures. 2011 Edition, London, Profile Books, 2010.

a little more than $6.5 \mathrm{Gt}$. With a total volume of emissions somewhat more than $29 \mathrm{Gt}$, it works out to more than 41 percent (19.0 percent for the United States and 22.3 percent for China) (12) (Table 4). To better understand the nature of some challenges (environmental and political) internal and external of the $\mathrm{G} 2$, it would be useful to place the snapshot data in a dual perspective - historical and prospective.

Table 4 gives a good picture of the changes in China: from a very low level in the 1970s and gradually, as its economy developed, catching up and overtaking total US emissions in 2007.

Nevertheless, there remains a considerable imbalance in the Chinese and US per capita emissions. This imbalance (1 American "equals" 3.7 Chinese) translates - approximating for clarity - into China, with a fifth of the world's population, accounting for a fifth of global $\mathrm{CO}_{2}$ emissions, and the United States, with less than 5 percent of the world population, emitting a fifth of the $\mathrm{CO}_{2}$ each year. The imbalance is actually even greater, as the 3.7 figure fails to account for carbon "exports" and "imports" engendered by international trade. In 2004, trade was responsible for 23 percent of global emissions of $\mathrm{CO}_{2}$, about $6.2 \mathrm{Gt}$. China exported 1,147 million tonnes (Mt) of $\mathrm{CO}_{2}$, while the United States imported $699 \mathrm{Mt}$. Given these figures, China is the world's top $\mathrm{CO}_{2}$ exporter and the United States the top importer. ${ }^{(13)}$ Keeping in mind their respective population sizes, ${ }^{(14)}$ these figures show that each American "imports" 2.36 tonnes of $\mathrm{CO}_{2}$ (699/296) while each Chinese "exports" 0.87 tonne $(1,147 / 1,310.5)$. The per capita difference is thus no longer 19.5 to 3.9 but $21.86(19.5+2.36)$ to 3.03 (3.9 - 0.87): Thus not a five-fold difference but 7.2-fold (21.86/3.03).

Apart from this, the two countries' responsibility for current global warming is likewise unequal. The United States was responsible for 30 percent of total $\mathrm{CO}_{2}$ emissions between 1900 and 2004, while China accounted for just 9 percent during that period. ${ }^{(15)}$ However, whereas each country's historical responsibility should of course be considered - and Beijing never misses an opportunity to say so - resolving the "climate question" cannot, out of concern for equality, be conditioned on Chinese per capita emissions reaching the US level (which is, it may be noted, double Japan's and triple France's).

That said, one of the major difficulties "post-Kyoto" lies in the expected growth in $\mathrm{CO}_{2}$ emissions over coming decades in developing and emerging (BRIC) countries, whose right to develop cannot be questioned.

No need to belabour this point. Between 1990 and 2008, global emissions of $\mathrm{CO}_{2}$ rose from $20,964.8 \mathrm{Gt}$ to $29,381.4 \mathrm{Gt}$, an increase of 40.1 percent. But this average hides highly contrasting nation- and region-wide changes. Countries that ratified the Kyoto protocol and adopted constraints reduced their emissions by 9.2 percent between 1990 and 2008. It should be added, however, that this figure is largely due to cuts made by economies in transition (the Annex I ElTs) ${ }^{(16)}$ (see Box). Emissions by Annexe II countries (Western Europe and North America, for example) actually rose by 12 percent. In 2008, for the first time, the emissions of "nonAnnex I" (17) countries overtook those of Annex I. Between 2007 and 2008, non-Annex I countries' emissions rose by nearly 6 percent, while those of Annex 1 fell by 2 percent.
As the International Energy Agency (IEA) noted, in 2008, developing countries' aggregate emissions were greater than those of developed countries, ${ }^{(18)}$ and everything indicates this trend will continue. The IEA estimates that $\mathrm{CO}_{2}$ emissions attributable to energy use, which totalled 28.8 $\mathrm{Gt}$ in 2007, would rise to $34.5 \mathrm{Gt}$ in 2020 and $40.2 \mathrm{Gt}$ in 2030 - that is, an annual growth of 1.5 percent. ${ }^{(19)}$ The IEA notes that non-OECD members account for the expected increase $(11.4 \mathrm{Gt})$, and that three-fourths of it will come from China.

\section{Annexes}

The terms used in the "Annexes" might seem rather confusing. Many articles refer to Annexes I and II and others to Annex B. Actually, the denominations refer to different legal texts. Annexes I and II and "non-I" stem from the United Nations Framework Convention on Climate Change - UNFCCC of 1992. Annex I consists of industrialised members of the OECD in 1992 plus economies in transition (Annex I EIT for Economies in Transition), including the Russian Federation, the Baltic States, and a number of Central and Eastern European states. The United States is in Annex I.

Annex II includes the OECD members of Annex I but not those of Annex I EIT.

The non-Annex I states are developing economies. China is a "nonAnnex I" country.

Annex B relates to the 1997 Kyoto Protocol, which followed the 1992 Framework Convention. Annex B includes Annex I countries that committed to measured cuts in greenhouse gas emissions. The United States figures in Annex B, but having repudiated the Kyoto protocol, it is exempt from reduction commitments. In practice, many people use Annex I and Annex B synonymously.

12. For comparison, Europe's 27 members represented $3.85 \mathrm{Ct}$ ( 0.37 for France and 0.80 for Germany), Japan 1.15Ct, and India 1.43Gt.

13. See Steven I. Davis and Ken Caldeira, "Consumption-based accounting of $\mathrm{CO}_{2}$ emissions," PNAS (Proceedings of the National Academy of Sciences), 23 March 2010, vol. 107, no. 12, pp. 5687-5692. Naturally, not all of China's $\mathrm{CO}_{2}$ exports are to the United States, nor are all of US imports of Chinese origin.

14. Data used are from 2005 of the International Energy Agency, $\mathrm{CO}_{2}$ Emissions from Fuel Combustion Highlights. 2010 Edition. US population: 296 million, Chinese population: 1,310.5 million. US emission per capita: 19.5 tonnes, Chinese emissions per capita: 3.9 tonnes, a 5:1 ratio.

15. OECD, The Economic of Climate Change Mitigation: Policies and Options for Global Action Beyond 2012, Paris, OECD, p. 204

16. Belarus, Bulgaria, Croatia, Czech Republic, Slovakia, Estonia, Hungary, Latvia, Lithuania, Poland, Romania, Russia, Slovenia and Ukraine.

17. Among them are major emerging countries, including China.

18. International Energy Agency, $\mathrm{CO}_{2}$ Emissions From Fuel Combustion, Highlights. 2010 Edition, op. cit., p. 7.

19. IEA, World Energy Outlook 2009. Document available on the IEA website. 
Table 4 - US and Chinese $\mathrm{CO}_{2}$ emissions (total* and per capita**) 1971-2008

\begin{tabular}{|c|c|c|c|c|c|c|c|}
\hline & & 1971 & 1980 & 1990 & 2000 & 2006 & 2008 \\
\hline \multirow[t]{3}{*}{ United States } & $\begin{array}{c}\text { Total } \\
\text { emissions }\end{array}$ & $\begin{array}{l}4,291.3 \\
(30.4 \%)\end{array}$ & $\begin{array}{l}4,661.6 \\
(25.8 \%)\end{array}$ & $\begin{array}{l}4,863.3 \\
(23.2 \%)\end{array}$ & $\begin{array}{l}5,693.0 \\
(24.2 \%)\end{array}$ & $\begin{array}{c}5,698.3 \\
(20.3 \%)\end{array}$ & $\begin{array}{l}5,595.9 \\
(19.9 \%)\end{array}$ \\
\hline & Population & $\begin{array}{c}207.7 \\
(5.5 \%)\end{array}$ & $\begin{array}{c}227.7 \\
(5.1 \%)\end{array}$ & $\begin{array}{c}250,2 \\
(4.7 \%)\end{array}$ & $\begin{array}{c}282.4 \\
(4.6 \%)\end{array}$ & $\begin{array}{c}299.2 \\
(4.6 \%)\end{array}$ & $\begin{array}{c}304.5 \\
(4.5 \%)\end{array}$ \\
\hline & $\begin{array}{l}\text { Emissions } \\
\text { per capita }\end{array}$ & 20.7 & 20.5 & 19.4 & 20.1 & 19.0 & 18.4 \\
\hline \multirow[t]{3}{*}{ China } & $\begin{array}{c}\text { Total } \\
\text { emissions }\end{array}$ & $\begin{array}{c}809.6 \\
(5.7 \%)\end{array}$ & $\begin{array}{l}1,420.0 \\
(7.9 \%)\end{array}$ & $\begin{array}{l}2,244.0 \\
(10.7 \%)\end{array}$ & $\begin{array}{c}3,077.6 \\
(13.1 \%)\end{array}$ & $\begin{array}{l}5,645.2 \\
(20.1 \%)\end{array}$ & $\begin{array}{l}6,550.5 \\
(22.3 \%)\end{array}$ \\
\hline & Population & $\begin{array}{c}845.2 \\
(22.5 \%)\end{array}$ & $\begin{array}{c}986.3 \\
(22.2 \%)\end{array}$ & $\begin{array}{c}1,140.9 \\
(21.7 \%)\end{array}$ & $\begin{array}{c}1,269.3 \\
(20.9 \%)\end{array}$ & $\begin{array}{c}1,318.7 \\
(20.2 \%)\end{array}$ & $\begin{array}{l}1,332.6 \\
(19.9 \%)\end{array}$ \\
\hline & $\begin{array}{l}\text { Emissions } \\
\text { per capita }\end{array}$ & 0.9 & 1.4 & 2.0 & 2.4 & 4.3 & 4.9 \\
\hline \multicolumn{2}{|c|}{ US/Chinese emissions per capita } & 23 & 14.6 & 9.7 & 8.4 & 4.4 & 3.7 \\
\hline \multicolumn{2}{|c|}{ World population } & $3,758.4$ & $4,435.4$ & $5,259.2$ & $6,072.7$ & $6,535.2$ & $6,687.9$ \\
\hline \multirow[t]{3}{*}{ Emissions } & World total & $14,095.0$ & $18,054.8$ & $20,980.5$ & $23,497.3$ & $28,028.0$ & $29,381.4$ \\
\hline & Total G2 & $5,100.9$ & $6,081.6$ & $7,107.3$ & $8,770.6$ & $11,343.5$ & $12,146.4$ \\
\hline & $\begin{array}{l}\text { Total G2 } \\
\text { world }\end{array}$ & $36.2 \%$ & $33.7 \%$ & $33.9 \%$ & $37.3 \%$ & $40.5 \%$ & $41.3 \%$ \\
\hline
\end{tabular}

Note: Total emissions are given in millions of tonnes of $\mathrm{CO}_{2}$, emissions per capita in tonnes of $\mathrm{CO}_{2}$, and the population in millions. Figures in brackets show the share of the world total. Source: Based on International Energy Agency data, $\mathrm{CO}_{2}$ Emissions From Fuel Combustion, Highlights. 2010 Edition. (Text available on the Internet).

\section{The G2 climate}

Obviously, drawing up a new "climate regime" has become imperative even as the climate within the $\mathrm{G} 2$ is less than favourable. Chris Patten perfectly summed up the challenge of the coming years: "The [Kyoto] Protocol distinguishes between developed countries, which have largely created today's problems, and developing countries, which need assistance to avoid creating tomorrow's." (20) It is thus high time the next stage was reached. It is all clear on paper: In order to prevent the earth's temperature from rising more than $2^{\circ} \mathrm{C}$ above the pre-industrial level, annual emissions have to stay below $14.5 \mathrm{CtCO}_{2}$. But we are already producing double that! Before attempting some reflections on what the future holds, it would be useful to take a (quick) stock of the Copenhagen and Cancun summits.

\section{Copenhagen to Cancun... awaiting Durban}

When the projectors were finally switched off at the Copenhagen Summit (Conference of Parties 15 or COP 15) (21) on 19 December 2009, the dominant opinion was, in the words of Herman Van Rompuy, that it was an "incredible disaster." More than a year later, it seems clear - as was foreseen (22) - that neither the United States nor China wanted a limiting multilateral accord. Revelations by WikiLeaks show that contrary to the wishes of Paris, Berlin, and London, there was no desire in Washington to exercise leadership on the climate issue. As for China's obstruction strategy, it was quickly revealed by a number of witnesses. However - and this no doubt was part of Beijing's calculations - most observers laid the blame squarely on the US.

While the Copenhagen summit was not, to say the least, an advance in terms of international coordination on climate issues, it nevertheless had some interesting results. This ultra-minority view in early 2010 received the backing of Christian de Perthuis and Annaic Delbosc. They conceded in an article that the Copenhagen text was not legally binding, unlike the Kyoto Protocol, but added that it nonetheless marked a turning point for two reasons. First, the Copenhagen commitments cover much more ground than the Kyoto Protocol. By including US emissions as well as those of emerging countries, the commitments target not 25 percent but rather 75 percent of global emissions of greenhouse gases. Second, the Annex I countries agreed to reduce their 2020 emissions by 12 percent of their 1990 level.

The major advance of the Copenhagen accords [they said] lay in greatly expanding the amount of greenhouse gases covered by the limits agreed. Of course, the scope of the agreements fall short of the levels IPCC recommended for Annex I countries. For developing countries, the commitments leave space for a rise in emissions that would be quite conducive to the pursuit of rapid growth by the major emerging countries. (23)

20. Chris Patten, What Next? Surviving the Twenty-first Century, London, Penguin Books, 2009, p. 369.

21. Each year, countries that have ratified the United Nations Framework Convention on Climate Change (1992) hold a "Conference of the Parties" (COP). The first was held in Berlin in 1995, the second in Geneva in 1996... the 15th at Copenhagen in 2009, and the 16th at Cancun in 2010. The 17th will take place in Durban, South Africa.

22. See Jean-Paul Maréchal, "Moins $40 \%$ d'un côté, plus $400 \%$ de l'autre!" (40\% less on the one hand, $400 \%$ more on the other), La Liberté (Fribourg, Switzerland), 2 December 2009, p. 8.

23. Christian de Perthuis and Anaïs Delbosc, "Négociations climatiques: les enjeux du post-Copenhague" (Climate negotiations: post-Copenhagen challenges), L'Économie politique, no. 46, 2010, p. 74. IPCC is the Intergovernmental Panel on Climate Change formed in 1988 at the initiative of the World Meteorological Organisation and the United Nations. At regular intervals, it puts out a summary of recent scientific work on both ongoing and foreseeable climate change. 
In the same vein, Nicholas Stern (24) said in June 2010 that the Copenhagen Conference was in many ways disappointing, but that it could have been much worse and that it did provide a basis for discussion towards an international treaty.

A year after this summit, which had inspired the most feverish excitement, the one in Cancun (COP 16) opened with quasi-indifferent media coverage. Of course the basic geopolitical reality had not changed. At a press conference on 22 November in Washington, Todd Stern, the US Special Envoy for Climate Change, said a treaty including quantified reduction commitments for Western countries should also apply to emerging ones such as China. (25) Two days later, Xie Zhenhua, deputy head of the National Development and Reform Commission, retorted, "Developed countries have to take the lead in reducing their carbon missions and making space for developing nations to prosper." He stressed that China will not accept any obligation beyond its ability as a developing country. (26)

The 194 countries that met in Mexico had to confront (at least) four challenges: save the Kyoto Protocol, conserve tropical forests, get a "Green Fund" going, and set up a monitoring mechanism to measure progress. At the outset Japan upped the stakes; vice-minister for environment Hideki Minamikawa said he was opposed to a second period of commitment to the Kyoto Protocol (the first ending in 2012), arguing that signatory countries accounted for just 27 percent of global greenhouse gas emissions. After 12 days of debate an agreement finally resulted.

A modest accord, (27) of course, but it nevertheless restored (a little) of the UN's credibility, and broke the cycle of failure Copenhagen seemed to have set off. Two advances are particularly noteworthy: the creation of a Green Fund and an extension of the Kyoto Protocol. The Green Fund is aimed at helping developing countries adapt to climate change, protect tropical forests, and switch to green technologies such as solar and wind. The Fund, under temporary World Bank control, is expected to command $\$ 100$ billion annually starting in... 2020. But the issue of intellectual property rights linked to technology transfers has been evaded. The Kyoto Protocol - the only legally binding international text on climate to date (but which binds neither the United States nor China to any emission cuts) - was extended by a year. The parties postponed until 2011 the negotiations on its future, or rather to ensure that there was no delay between the first and second commitment periods ... should there be a second one. In addition, the text reaffirms that industrialised countries would have to reduce emissions of greenhouse gases by 25 percent to 40 percent by 2030. And emerging giants such as China and India would commit to submitting, once every two years, reports on their emissions and on the measures taken to reduce them. These, the text hastened to add, would be subject to international consultations and analysis that were "non intrusive," "non punitive," and "respecting national sovereignty"... No comment...

As Christiana Figueres, the UN climate chief said, "it is not the end, it is just the beginning." (28) But the beginning of what? What can be expected from COP 17, which convenes in late 2011 at Durban? What is there to be optimistic about ... when there is so much reason not to be?

\section{The ruse of reason and the invisible hand to climate's rescue?}

Progress sometimes takes strange turns. Although Sino-US cooperation in reversing climate change is not on the agenda, two factors give cause for optimism: rivalry in the matter of green technologies, and the air pollution problems currently vexing the Chinese.

President Obama's speech on 24 February 2009 to the two houses of Congress gives a good inkling of the tone:

We know the country that harnesses the power of clean, renewable energy will lead the 21st century. And yet, it is China that has launched the largest effort in history to make their economy energy efficient. [...] But to truly transform our economy, protect our security, and save our planet from the ravages of climate change, we need to ultimately make clean, renewable energy the profitable kind of energy. (29)

A priori, however, the United States is well placed to face this challenge. In 2009, it was the world leader in the Innovation Index, while China did not figure among the top 24. ${ }^{(30)}$ In terms of research and development spending, it is well ahead of China by any yardstick (total expenditure of percentage of GDP - Table 5). The same goes for patents: for 2005-2007, the United States had 81,329 (second behind Japan, which had 127,644) against 25,909 for China (fifth).

However, analyses of these figures tend towards nuancing, though not discounting, what they may suggest at first glance.

Table 5 is a case in point. Between 2006 and 2007, spending on research and development rose by 7.3 percent in the United States, against 29 percent in China. Although the base amount is almost 10 times higher in the United States than in China, the percentage comparison remains significant. According to China's State Intellectual Property Office, 580,000 patents were filed in 2009, or 41 percent more than the previous year and five times that in 2001. Further, a growing proportion of these are "invention patents" (not merely improvements on existing inventions) and are held by Chinese companies. China also holds an increasing number of patents abroad. In 1999, for example, 90 Chinese patents were granted in the United States; in 2008, this rose to 1,225. (31) UNESCO's 2010 Science Report considers it almost certain that China will henceforth be the country with the largest number of researchers: There were 1.59 million in 2008. To grasp the magnitude of the progress: China had 1.423 million researchers in 2007 and... 695,000 in 2000 - a 229 percent increase in eight years. ${ }^{(32)}$ Between 2000 and 2008, the value of China's high technology exports to the United States rose from $\$ 28$ billion to $\$ 112$ billion. ${ }^{(33)}$

24. Nicholas Stern, "Climate: What you Need to Know," The New York Review of Books, vol. LVII, no. 11, 24 June 2010, pp. 35-37.

25. "Briefing on Upcoming United Nations Climate Change Meeting"(document available at America.gov).

26. Li Jing, "China to Take Active Role at Climate Talk," China Daily, 24 November 2010.

27. Of the 194 countries present, Bolivia was the sole dissenter.

28. See Christian Losson, "Cancún: le sommet se raccroche aux branches" (Summit seeks to end a sticky situation), Libération, 15 December 2010, pp. 18-19.

29. Speech available on the White House website.

30. See The Economist, Pocket World in Figures. 2011 Edition, op. cit., pp. 62-63. The innovation index is a measure of the adoption of a new technology, and the interaction between the business and the science sectors. It includes measures of investment in research institutions and protection of property rights.

31. See Sylvie Kauffmann, "La Chine entend devenir le laboratoire du monde" (China seeks to be the world's laboratory), in Le Monde, Bilan géostratégie, Édition 2010, Paris, Le Monde, pp. 164-165.

32. UNESCO Science Report 2010, Paris, UNESCO Publishing, 2010, p. 390. The report notes that the term "researcher" here refers to scientists and engineers among R\&D personnel in the Chinese statistical yearbooks, a comparable indicator to "researchers" in OECD statistics.

33. National Science Board, Science and Engineering Indicators 2010, p. 0-18. (Text available on the National Science Board website). 
Table 5 - Total R\&D expenditure (2006 and 2007)

\begin{tabular}{c|c|c|c|c|c|c|c|c|c|c}
\multicolumn{2}{c|}{ World ranking } & Country & \multicolumn{2}{c|}{ As \% of GDP } & \multicolumn{2}{c|}{ World ranking } & \multicolumn{2}{c|}{ Country } & \multicolumn{3}{c}{ Amount (In billions of dollars) } \\
\hline 2006 & 2007 & & 2006 & 2007 & 2006 & 2007 & & 2006 & 2007 & $\Delta \%$ \\
\hline 7 & 7 & US & 2.61 & 2.67 & 1 & 1 & US & 343.7 & 368.8 & $7.3 \%$ \\
\hline 23 & 23 & China & 1.36 & 1.49 & 6 & 5 & China & 37.7 & 48.8 & $29 \%$ \\
\hline
\end{tabular}

Source: The Economist, Pocket World in Figures. 2010 Edition, London, Profile Books, 2009, p. 63 and The Economist, Pocket World in Figures. 2011 Edition, London, Profile Books, $2010,63$.

Table 6 - Available information on R\&D investment in the field of energy

\begin{tabular}{|c|c|c|c|c|c|c|c|}
\hline $\begin{array}{c}\text { In million } 2008 \\
\text { PPP \$Int }\end{array}$ & $\begin{array}{c}\text { Fossil } \\
\text { (incl. Carbon } \\
\text { capture } \\
\text { and storage) }\end{array}$ & $\begin{array}{c}\text { Nuclear } \\
\text { (incl. fusion) }\end{array}$ & $\begin{array}{l}\text { Electricity } \\
\text { transmission, } \\
\text { distribution } \\
\text { and storage }\end{array}$ & $\begin{array}{c}\text { Renewable } \\
\text { energy } \\
\text { sources }\end{array}$ & $\begin{array}{l}\text { Energy } \\
\text { efficiency }\end{array}$ & $\begin{array}{c}\text { Energy } \\
\text { technologies } \\
\text { (not specified) }\end{array}$ & Total \\
\hline China & 6,755 & 12 & $N A^{*}$ & NA & 136 & 4,900 & 11,803 \\
\hline United States & 659 & 770 & 319 & 699 & 525 & 1160 & 4,132 \\
\hline
\end{tabular}

* Data not available.

Source: Ruud Kempener, "Energy innovation policy in major emerging countries," text available on the Belfer Center for Science and International Affairs website: (http://www.belfercenter.org/).

This is reflected in the area of "green" technologies as well. China has become the world's top producer of low energy light bulbs, wind turbines, solar panels, solar water heaters (60 percent of the global market), batteries for electric cars, and so on. ${ }^{(34)}$ According to a 2010 World Bank report, ${ }^{(35)}$ China is fast developing technological innovations in renewable energy, representing 0.7 percent of its patents between 2003 and 2005 against 0.3 percent for the United States. Some experts say China will soon overtake older industrial countries in drawing up norms for environmental products. In short, China aims to prevail in future markets, especially those for "clean" products, in which the Westerners have ceded incontestable leadership. According to the Washington-based Pew Environment Group Climate and Energy Program, China in 2009 invested \$34 billion in clean technologies, whereas the United States devoted just $\$ 18.6$ billion. ${ }^{(36)}$ As Todd Stern said at the press conference mentioned earlier:

(I)ntensive effort to work on the electrification of the vehicle fleet and the production of electric cars in the United states (...) could be a very good thing for our auto business, for creating jobs, for manufacturing in Ohio and Michigan, for example (...) So I think that there are things that will be doable even with people who are - who do not profess belief in what science is obviously telling us all.

But Sino-US competition is also raging in more traditional energy technologies. Thus, according to the Belfer Center for Science and International Affairs (Harvard University), Chinese and US investment in energy-related $R \& D$ in 2008 was $\$ 11.8$ billion and $\$ 4.1$ billion respectively (Table 6).

Unintended consequences of commercial rivalry could thus be positive for the "greening" of economic growth. Added to this is China's evident interest in combating air pollution, which has become a nationwide problem.

China confronts ecological problems of gigantic proportions that show up at all levels and touch all sectors. A report of the World Bank and SEPA (State Environmental Protection Administration) in 2007, which was cut and censored at the Chinese government's request, estimated that pollu- tion causes 750,000 deaths in China each year. A government report in 2007 put out by the official Xinhua News Agency put China in 100th place out of 118 developed and developing nations classed according to an ecological modernisation indicator. ${ }^{(37)}$ In 2006, Yale University's environmental performance index ranked China $94^{\text {th }}$ out of 133 countries. ${ }^{(38)}$

These problems mainly hit the most vulnerable, reinforcing social inequality and exacerbating popular discontent. Thus, according to the Chinese Academy of Social Sciences, incidents of social unrest rose from 40,000 in 2001 to more than 90,000 in 2009. The Academy has noted that incidents have increased in scope. ${ }^{(39)}$ It is estimated that some 51,000 incidents were linked to pollution in $2005^{(40)}$ - an impressive statistic, and it should be noted that air pollution alone (which concerns us here) causes at least 350,000 deaths annually. ${ }^{(41)}$

This explains "increasing" moves that could translate environmental concerns into solutions that would help limit emissions of greenhouse gases. ${ }^{(42)}$ In general, it should usher in measures linking the aims dear to the leaders of emerging countries (economic growth, security, air quality... ) with the fight against climate change.

Examples abound. To illustrate, it might be pointed out that reducing emissions of "black carbon" or ozone would rapidly improve living conditions for millions of Chinese. ${ }^{(43)}$ "Black carbon" stands for carbon particles

34. See Le Point, 24-31 December 2009, no. 1945-1946, pp. 122-123, and The World Bank, World Development Report 2010. Development and Climate Change, p. 205 (document available on the World Bank's website)

35. The World Bank, World Development Report 2010, op. cit., p. 292.

36. See Chen Weihua, "China Will Continue to Go Green," China Daily, 23 November 2010.

37. Li Ma and François Schmitt, "Development and Environmental Conflicts in China," China Perspectives, no. 2, 2008, pp. 94-102.

38. Benoît Vermander, Chine brune ou Chine verte. Les dilemmes de l'État-parti (Brown China or Green China: Dilemmas facing the state and Party), Paris, Les Presses de Sciences Po, 2007, p. 58.

39. Voir George J. Gilboy and Eric Heginbotham, "China's Dilemma: Social Change and Political Reform," Foreign Affairs, 14 October 2010 (article on Foreign Affairs website).

40. Li Ma and François Schmitt, "Development and Environmental Conflicts in China," op. cit., pp. 94-102.

41. Benoît Vermander, Chine brune ou Chine verte, op. cit., p. 65.

42. Michael A. Levi, "Copenhagen's Inconvenient Truth: How to Salvage the Climate Conference?", Foreign Affairs, vol. 88, no. 5, September-October 2009, pp. 92-105.

43. See Jessica Seddon Wallack and Veerabhadran Ramanathan, "The Other Climate Changers: Why Black Carbon and Ozone Also Matter," Foreign Affairs, vol. 88, no.5, September-October 2009, pp. 105-113. 
that lend smoke its black or brown colour. Its warming effect is between 20 percent and 50 percent of $\mathrm{CO}_{2}$ (an invisible gas). ${ }^{(44)}$ As for ozone ${ }^{(45)}$ (formed through combination of "precursor" gases such as carbon monoxide and methane), its warming potential is about 20 percent that of $\mathrm{CO}_{2}$. As these two types of emissions have localised consequences - that is, their effects can be felt locally - a government would be inclined to limit their volume. In fact, reducing emissions of ozone precursors would have positive impact on food production, reduce black carbon release, and benefit people's health without affecting their lifestyle.

Beijing seems to realise the importance of these challenges, the more so as the economy's energy demand is likely to keep growing in the coming decades. The IEA's prognosis is that China's $\mathrm{CO}_{2}$ emissions will nearly double by 2030 . Striking though this might appear, this figure is based on the hypothesis of a rate of annual growth of these emissions being of the order of only 2.9 percent, whereas it was actually 16 percent in 2003, 19 percent in 2004, 11 percent in 2005 and 2006, and 8 percent in 2007 and 2008. In 2008, power and heat production represented 48 percent of total emissions, against 7 percent for transport, for instance. In fact, as the IEA has said, electricity demand has been and will be the main factor behind growing $\mathrm{CO}_{2}$ emissions to the extent that about four-fifths of its production is by thermal plants. ${ }^{(46)}$ In 2009, China's electricity production capacity rose by 81 gigawatts, a little over the total capacity of South Korea. (47) It is therefore understandable that the 11th Five Year Plan (2006-2010) envisaged reducing energy intensity by 20 percent, and that a major focus of the 12th Plan (2011-2015) is not only to pursue efforts towards reducing emissions of pollutants and conserving energy but also to reorient China's economy towards a green development model and lower carbon intensity. It was also with the aim of reducing dependence on polluting resources that China decided to build 28 nuclear reactors by 2020, a program more or less confirmed after the Japanese nuclear disaster of March 2011. In the administrative domain, there has been the transformation of SEPA into the Ministry of Environment Protection in 2008.

Further, leading academics and government representatives have taken highly encouraging stands. Among them is Hu Angang, one of China's bestknown economists. The Tsinghua University professor proposed in an article in 2009 (before the Copenhagen Conference) (48) that each country's emission reduction obligations should be assessed in relation to its development level, its emissions per capita, and its total emissions. China would then have to "accept its responsibilities," he said. "The authorities at present haven't realised this and have clearly not taken facts into consideration."

$\mathrm{He}$ is far from being alone. In fact, a wide-ranging debate took place in China in 2009 on the possible adoption of a carbon tax. ${ }^{(49)}$ Many administrations and scholars voiced support for the move. Some defend this stand, a little like $\mathrm{Hu}$, by stressing the fact that the adoption of such a measure would boost China's credibility on the international scene. Others, more focused on the near term, see in it a means of countering the threat held out by some Western countries of introducing a carbon tax at the border. This arguably shows that international pressures can (sometimes) have positive effects. It is regrettable in this context that there was no follow-up to Joseph Stiglitz's proposal of a few years ago to levy a tax on US imports of products made by enterprises emitting greenhouses gases. This winner of the 2001 Nobel Prize for Economics argued that such a tax would counter the competition distortion benefiting countries that were not parties to the Kyoto Protocol. (50)
However, as for the G2, nothing has changed. All indications are that the Chinese middle class will keep growing - and this can hardly be deplored - and that pressure on the environment will increase. An OECD working document published in January 2010 predicts that by 2030, five billion people will belong to the middle class (defined as households with daily expenses of between $\$ 10$ and $\$ 100$ in PPP). Homi Kharas (author of the OECD text) and Geoffrey Gertz, in a book published the same year, envisage a Chinese middle class of 670 million people against some150 million today. ${ }^{(51)}$ Besides, climate negotiations are just one among many themes in the Sino-US rivalry. It was perhaps not unintended that in the weeks following the Copenhagen summit, President Obama received the Dalai Lama at the White House and authorised more than $\$ 6$ billion worth of arms sales to Taiwan.

\section{Conclusion}

Evidently, climate is now hostage to the G2. As Chris Patten says, "China will not move without America, and America will not move without China. They are locked together. An agreement between them is vital to saving the century." (52)

Given this "confidence building" problem, the best that can be hoped for in the coming years would be for climate conferences to lead to a cycle of negotiations, as in the case of disarmament - the technicalities of which they have borrowed - or trade talks, the slow pace of which they share. One peculiarity of climate negotiations is that they never pick up where they left off. The longer the delay, the further the ecological situation deteriorates and the more difficult (and costly) it becomes. At the same time, the need for remedy becomes more urgent. Further, global warming could contribute to provoking or exacerbating conflicts or giving rise to new international rivalries. The case of melting ice on the North Pole perfectly illustrates the state of affairs. The Arctic had been a zone of cooperation, but once it became possible to steer ships there and exploit energy and mineral resources at short notice, it became a bone of contention. It is thus no exaggeration to say that whatever may be said about human activity's role in climate change, "decarbonisation" of the economy would be a highly desirable aim simply from a security angle. •

\section{Translated by N. Jayaram}

44. See Orville Schell, "The Messages from the Glaciers," The New York Review of Books, vol. LVII, no. 9, 27 May to 9 June 2010, pp. 46-50.

45. This does not refer to stratospheric ozone blocking the sun's rays.

46. See Jean-Marie Martin-Amouroux, "Chinese Coal and Sustainable Development," China Perspectives, no. 1, 2007, pp. 30-39.

47. International Energy Agency, $\mathrm{CO}_{2}$ Emissions From Fuel Combustion, Highlights. 2010 Edition, op. cit., Pp. 24-25.

48. Angang Hu, "A New Approach at Copenhagen (1) (2) (3)," Chinadialogue, 6 April 2009 (text available at http://www.chinadialogue.net).

49. See Thomas Vendryes, "Carbon tax: How the debate has fared," China Perspectives, no. 2, 2010, pp. 7475.

50. See Joseph Stiglitz, Making Globalization Work, New York, W.W. Norton \& Company, 2006, chap. 6.

51. See Homi Kharas, "The Emerging Middle Class in Developing Countries," OECD Development Centre, Working Paper no. 285, January 2010; Homi Kharas and Geoffrey Gertz, "The New Global Middle Class: A Cross-Over from West to East," in Cheng Li (ed.), China's Emerging Middle Class Beyond Economic Transformation, Washington, DC, Brookings Institution Press, 2010, pp. 32-51.

52. Chris Patten, What Next? Surviving the Twenty-first Century, op. cit., p. 379. 